\title{
O princípio da legalidade tributária *
}

\author{
Gerd W. Rothmann
}

Sumário. 1. Apresentação. 2. Introdução. 2.1 o poder de tributar. 2.2 Limitações ao poder de tributar decorrentes do principio do Estado de Direito. 2.2.1 Conceito de Estado de Direito. 2.2.2 O Estado de Direito na Constituição Federal. 2.2.3 $O$ principio do Estado de Direito no Direito Tributario.

3. Origem histórica e Conceito do Princfpio da Legalidade TRIBUTÁRIA. 3.1 Origem histórica da legalidade tributária. 3.2 Conceito da legalidade tributária.

4. As Feições do Princtpio da Legalidade Tributária. 4.1 Legalidade da administração. 4.2 Reserva da lei. 4.3 Estrita legalidade tributária. 4.4 Conformidade da tributação com o fato gerador.

5. O Conceito de "Leil" para Efettos do Princfiolo da Estrita Legalidade Tributária - Legalidade Material e Formal.

6. O Princfipio da Legalidade Tributária e a Aplicação e INTERpretação das Leis Tributáias. 6.1 aplicação das leis tributárias. 6.2 Interpretação das leis tributarias. 6.3 Integraçăo das leis tributarias - Analogia e equidade. 6.4 Consideração econômica. 6.4.1 Natureza económica das leis tributárias. 6.4.2 Aspectos da consideração económica - Teoria dos tipos e "Durchgriffslehre". 6.5 Retroatividade das leis tributarias.

7. Conclusōes E Bibliografia.

\section{Apresentação.}

O princípio da legalidade tributária, objeto do presente trabalho, é o fundamento de toda a tributação, sem o qual não há como se falar em Direito Tributário. De fato, é a ne-

- Trabalho apresentado no Curso de Doutorado, na cadeira de Direito Tributário Comparado, sob orientação e regência do Professor Catedrático RuY barbosa Noguetra, na Faculdade de Direito da usp. 
cessidade de uma base legal que transforma a relação tributária em relação jurídica, retirando-a do campo do mero arbítrio.

O Estado, quando se dirige aos cidadãos, a fim de exigir-lhes uma contribuição pecuniária destinada ao custeio dos serviços públicos, encontra, por parte dêstes, maior ou menor resistência à sua pretensão. Ê exatamente neste campo da tributação que o Estado e os cidadãos entram em choque mais direta e frequientemente. Compor o conflito de interesses entre Estado e cidadãos é a função precípua do Direito Tributário, como disciplina jurídica das relações entre o Estado, na qualidade de Fisco, e os cidadãos, como contribuintes. Para tanto, o Direito Tributário se baseia no princípio da legalidade dos tributos, que, aliás, constitui a própria base do Direito Constitucional moderno, visto que o Estado de Direito nasceu de razões tributárias.

Em vista da importância fundamental do princípio da legalidade tributária, tem o presente trabalho a finalidade de estudar-lhe a origem histórica, a conceituação, suas diversas feições e seus corolários no campo da aplicação e interpretação das leis tributárias. Além de examinar o referido princípio no âmbito do Direito Tributário Comparado, pretendemos estudar sua validade face ao atual direito positivo do Brasil.

\section{Introdução.}

\subsection{O poder de tributar.}

São múltiplas as funções e tarefas atribuídas ao Estado, ente político criado pelos indivíduos para atender às necessidades coletivas. No estado contemporâneo, que se caracteriza por sua crescente intervenção na esfera econômica e social, as atividades do Estado se multiplicam. Para a realização dos seus fins, isto é, o atendimento das necessidades coletivas, o Estado, evidentemente, precisa de recursos materiais. A ob- 
tenção e a aplicação dos recursos materiais necessários ao custeio dos serviços públicos constitui a chamada atividade financeira do Estado, atividade que condiciona todas as demais atividades estatais.

Dirigindo-se aos cidadãos a fim de retirar-lhes uma parcela do seu patrimônio particular, o Estado se baseia na sua soberania, exercendo seu poder de mando ("ius imperii"). $\mathrm{O}$ fundamento desse poder de mando, que se expressa no seu poder de tributar, reside na necessidade de o Estado dispor dos meios para a realização dos seus fins, sob pena de perecer. 'Tendo nascido com a função precípua de prover as necessidades coletivas, o Estado há de estar munido do poder de exigir dos indivíduos uma participação nos encargos financeiros. $\mathrm{O}$ poder de tributar 'é, portanto, uma decorrência inevitável da soberania que o Estado exerce sobre as pessoas de seu território, ao qual corresponde, por parte dos indivíduos, um dever de prestação.

O poder de tributar, também chamado pelos autores de "soberania fiscal", constitui parte da soberania financeira do Estado, que, por sua vez, é parcela da soberania geral do Estado. A soberania financeira abrange todo o sistema financeiro do Estado, englobando receitas e despesas públicas, enquanto que a soberania fiscal diz respeito apenas a uma parte das receitas públicas, a saber, tributárias ${ }^{1}$

Considerando o poder coercitivo que está presente nas pretensões tributárias do Estado, discutiu-se muito se a relação obrigacional tributária representa uma relação de poder ("Gewaltverhaeltnis") ou uma relação de direito ("Rechtsverhaeltnis") Assim, a maioria dos autores alemães, como por exemplo Ottmar Buehler, considerando a realidade da tributação, admite uma relação de poder ${ }^{2}$ Defendendo o pon-

1. cf. H. W. KRUSE, Steuerrecht, I. Allgemeiner Teil, 2. Auflage, Muenchen, 1969, pág. 27.

2. Cf. Dino JARACH, Curso Superior de Derecho Tributärio, ed. nueva, Buenos Alres, 1969, pág. 157. 
to de vista contrário, Albert Hensel demonstra, a nosso ver com toda a procedência, que a sujeição do contribuinte ao poder do Estado somente consiste no fato de ele ter que atender à norma jurídica e que o Estado, mediante o uso de seu poder de coação, deve executar a vontade da lei. $\mathrm{O}$ poder de coação se subordina, portanto, à reserva genérica da lei, esgotando-se no momento da criação da lei. Como acentua HENSEL:

"Em vista da vinculação à lei, tanto do Estado, na qualidade de credor, como do devedor tributário, o primeiro não pode ser considerado "persona potentior". A norma jurídica e especialmente o fato gerador criam a plataforma jurídico-tributária comum, na qual o Estado e a pessoa que realiza o fato gerador se situam em posição de igualdade, como credor e devedor" 3

Concluímos, pois, que é exatamente em virtude do princípio da legalidade que a relação jurídico-tributária se caracteriza como relação de direito e não de poder, não havendo nenhuma supremacia de uma das partes sobre a outra. Esta igualdade das partes perante a lei se revela em toda sua plenitude na hipótese do pagamento indevido do tributo, onde as posições de credor e devedor se invertem, cabendo ao contribuinte o direito de pedir a restituição do indébito.

2.2 Limitações ao poder de tributar decorrentes do princípio do Estado de Direito.

\subsubsection{Conceito de Estado de Direito.}

Subordinando as atividades dos seus órgãos, entre elas a atividade financeira, à primazia da lei, os estados modernos se qualificam como Estado de Direito. Assim, à primeira

3. AlBert HeNSEL, apud H. W. KRUSE, Gesetzmaessige Verwaltung, Tatbestandsmaessige Besteuerung, in "Vom Rechtsschutz im Steuerrecht", Duesseldorf, 1960, pág. 110. 
vista, poderíamos conceituar o Estado de Direito como "aquêle em que governantes e governados, desde que estabelecida a regra jurídica, com o consentimento destes, a ela estão obrigados" 4 .

Nesta primeira acepção, puramente formal, o Estado de Direito, que aparece, em decorrência do constitucionalismo, a partir de meados do século passado, se reveste das características da separação dos poderes, legalidade da administração pública, reserva da lei formal e justiça independente em questões administrativas.

No entanto, a experiência revelou que as mencionadas características formais ainda não fazem com que um estado sealmente possa merecer a denominação de Estado de Direito ("Rechtsstaat"). Externamente, um estado pode deixar intocáveis tais princípios estruturais e, apesar disso, estar muito longe de realizar a justiça. Neste sentido, SAN Thiago Dantas, distinguindo a legalidade socialista da democrática, observa:

"O que caracteriza a legalidade socialista, e permite, desde logo, diferenciá-la da legalidade democrática é que ela sujeita à supremacia do direito os indivíduos e os órgãos administrativos do Estado, mas não o governo" 5

Portanto, o conceito de Estado de Direito deve partir do conteúdo material e não dos fenômenos formais. Somente quando o governo esteja disposto a realizar a idéia da justiça, criando efetivas garantias institucionais para os direitos das pessoas subordinadas ao seu poder, é que poderemos falar em Estado de Direito ${ }^{6}$ Nesta acepção material, Maunz conceitua o Estado de Direito

4. J. M. de Arruda Alvim Netto, Da Jurisdição, in Rev. D. Públ. 13/70 pág. 74.

5. San thisgo Dantas, apud J. M. de arruda alvim Netto; op. cit., pág. 74.

6. cf. JUERGEN SALZWEDEL, Rechtsstaat im Steuerrecht, in "Vom Rechtsschutz Im Steuerrecht", op. cit., pág. 59. 
"als Staat dessen Ziel die Erlangung und Erhaltung der materiellen Gerechtigkeit im staatlichen und staatlich beeinflussbaren Bereich ist" 7

ou em vernáculo

"como estado, cuja finalidade consiste na consecução e manutenção da justiça material, na própria esfera estatal e na esfera que possa ser influenciada pelo estado"

A forma de evitar arbítrio e abuso de poder e os meios de defesa concedidos às pessoas atingidas são de importância secundária. De qualquer modo, a separação dos poderes, os princípios da legalidade da administração pública e da reserva da lei são os meios formais de garantia jurídica mais utilizados.

\subsubsection{O Estado de Direito na Constituição Federal.}

O conceito de Estado de Direito da nossa Constituição Federal vigente não pode ser apreendido à primeira vista. Não possui a Constituição dispositivo expresso a respeito. Decorre, pelo contrário, da concepção global da Constituição, consubstanciada em uma série de princípios constitucionais. Como elementos do princípio do Estado de Direito, contidos na Constituição Federal, podemos citar especialmente os seguintes:

a) o princípio da separação dos poderes em Legislativo, Executivo e Judiciário, poderes esses independentes e harmônicos (art. 6. ${ }^{\circ}$ da Const. Fed.) ;

b) a garantia dos direitos individuais concernentes à vida, à liberdade, à segurança e à propriedade, nos termos do artigo 153 e parágrafos da Const. Federal;

c) o conceito da lei formal, elaborada com a participa-

7. Maunz/DueriG, Grundgesetz, comentário no 59 ao art. 20 da. const. alemã. 
ção da representação popular (art. 46 segs. da Const. Fed.);

d) o princípio da reserva da lei (art. 153, $\$ 2{ }^{\circ}$ Const. Fed.);

e) a tutela judiciária, por juízes independentes, especialmente quando se tratar de lesão de direito individual por parte do Poder Público (art. 153, $\$ 4 .^{\circ}$, combinado com os artigos $6^{\circ}$ e 113 da Const. Fed.)

Esta enumeração, no entanto, não esgota todos os elementos do princípio do Estado de Direito. Aliás, a própria Constituição Federal, no § 36 do seu artigo 153, estabelece:

"§ 36 - A especificação dos direitos e garantias expressos nesta Constituição não exclui outros direitos e garantias decorrentes do regime e dos princípios que ela adota"

Daí decorre que o Estado de Direito delineado pela Constituição somente representa um mínimo constitucional. Segue, portanto, que a legislação ordinária perfeitamente poderá ultrapassar as exigências mínimas da Constituição, visto que esta não definiu o Estado de Direito "ideal" O conceito de Estado de Direito contido na Constituição Federal é, portanto, um conceito que permite, mas não exige, o aperfeiçoamento do Estado de Direito através da legislação ordinária.

\subsubsection{O princípio do Estado de Direito no Direito Tributário.}

O princípio do Estado de Direito material, tal como delineado pela Constituição Federal, é da maior relevância para o Direito Tributário. Dele decorre que o Estado, no exercício da tributação, também deve ser "justo", no sentido de executar a arrecadação dos meios materiais necessários à realização dos seus fins, salvaguardando a justiça e os direitos de 
liberdade e propriedade dos contribuintes, sujeitos ao seu poder ${ }^{8}$.

No que se refere ao Direito Tributário, o princípio da separação dos poderes foi garantido constitucionalmente pela criação de órgãos especiais e independentes, encarregados, respectivamente, da legislação tributária, da administração e da jurisdição em matéria tributária. No entanto, a separação dos poderes não foi realizada de forma perfeita pela Constituição Federal vigente, que prevê a possibilidade de serem baixadas leis tributárias pelo Poder Executivo (decretos-leis do art. 55 da Const. Fed.) Nesta hipótese, a legislação e a aplicação das leis tributárias se encontram centralizadas no mesmo poder. Esta questão ainda será examinada no item 5, abaixo.

Além disso; a Constituição Federal ainda prevê uma série de garantias explícitas e implícitas em matéria tributária, tais como ${ }^{9}$
a) a legalidade tributária
b) a uniformidade da tributação
c) a igualdade jurídico-tributária
d) a anualidade das leis tributárias
e) o direito de propriedade
f) a liberdade profissional
g) a tutela jurisdicional
h) a irretroatividade das leis tributárias.

\section{Origem histórica e conceito do princípio da legalidade tributária.}

\subsection{Origem histórica da legalidade tributária.}

Como demonstrou Drewes na sua dissertação Die steuer-

8. Cf. Juergen Salzwedel, op. cit., pág. 63.

9. Cf. Antonio J. Franco De Campos, Das Garantias Juridicas no Direito Tributário, in "Direito Tributário", 3.a Coletânea, S. Paulo, 1971, pág. 37 e segs. 
rechtliche Herkunft des Grundsatzes der gesetzmaessigen Verwaltung ${ }^{10}$, o princípio da legalidade ou reserva da lei, tal como hoje se apresenta no $\$ 2 .^{\circ}$ do art. 153 da Constituição Federal, tem sua origem ligada à tributação.

De fato, foi em 1215 que na Inglaterra a nobreza e a plebe unidas impuseram ao príncipe João um estatuto que, antes de mais nada, visou a coibir-lhe a atividade tributária absolutamente extorsiva. Este estatuto, que representa a primeira constituição inglêsa, é conhecido como Magna Charta Libertatum, expressão do anseio de liberdade e conseqüente limitação dos poderes do Estado. No seu artigo XII, a Magna Carta estabelece que:

"no scutage or aid shall be imposed on our kingdom unless by the common counsel of our kingdom, except for ransoming our person, for making our eldest son a knight, and for once marrying our eldest daughter, and for these there shall not be levied more than a reasonable aid" ${ }^{11}$

Aí encontramos uma primeira idéia de autorização da cobrança de impostos e tributos em geral. E exatamente a autorização dos tributos por aqueles que os devem pagar, que distingue a tributação da simples desapropriação, tornando-a consentida ${ }^{12}$

Na Inglaterra, o Conselho dos Comuns, órgão encarregado da autorização da arrecadação, com o decorrer dos tempos se transformou em autêntico órgão de representação popular, constituindo-se no Parlamento, na Câmara dos Comuns, que não só autoriza a arrecadação, mas assume o controle da própria despesa pública. Assim, o nascimento e desenvolvimento do parlamento estão intimamente ligados ao problema do consentimento da tributação.

10. Citado por Kruse, Steuerrecht, op. cit., pág. 29.

11. Cr. Victor Uckmar, Principi Comuni di Diritto Costituzionale Tributario, Padova, 1959, pág. 10.

12. Cf. KRUSE, Gesetzmaessige Verwaltung..., op. cit., pág. 113 e segs. 
Também o movimento que culminou na independência dos Estados Unidos e a própria revolução francesa em grande parte foram consequiência da atividade tributária extorsiva e arbitrária do Estado. Eis porque, ambos os movimentos erigirem a princípio constitucional a limitação do poder de tributar. Assim, na Constituição norte-americana de 1787 (art. I, Seção 8. ${ }^{\mathrm{a}}$ ), foi atribuído expressamente ao Congresso, isto. é, ao órgão de representação popular, o poder

"to. lay and collect taxes, duties, imposts and excises, to pay debts and provide for the common defence and general welfare of the United States".

Por seu lado, as Déclarations des Droits de 1789 consagram, no seu artigo 13 , o princípio de que

"l'impôt ne peut être voté que par la nation ou ses representants.

Conforme nos atesta VICTOR UCKMar, todas as constituições vigentes, com exceção da constituição da União Soviética, contêm dispositivo expresso exigindo a aprovação dos impostos pelos órgãos legislativos competentes ${ }^{13}$ Quanto ao Brasil, o princípio da legalidade tributária foi consagrado por todas as constituições, com exceção da Carta de 1937 E tal é a importância deste princípio, que já a Constituição de 1891, além de reproduzí-lo na parte relativa à competência do Poder Legislativo (art. 34, itens 1 a 4), o elevou à categoria de direito individual, incluindo-o na Declaração de Direitos (art. $72, \S 30)^{14}$

Da mesma forma, a Constituição Federal vigente de 1967, na redação dada pela Emenda Constitucional n. $.^{\circ} 1 / 69$, contempla o princípio da legalidade tributária em dois capítulos distintos: primeiro, no capítulo dedicado ao Sistema Tribu-

13. Victor Uckmar, op. cit., pág. 21.

14. Cf. Paulino JaCQues, Curso de Direito Constitucional, $3 .{ }^{\mathrm{a}}$ ed: S. Paulo Rí, 1962, pág: 234. 
tário Nacional, onde o princípio da legalidade é expresso como uma proibição dirigida aos poderes tributantes - União, Estados, Distrito Federal e Municípios - de "instituir ou aumentar tributo sem que a lei o estabeleça.. " (art. 19, I da Const. Fed.) e, segundo, no Capítulo dos Direitos e Garantias Individuais, ao qual pertence historicamente, e onde é expresso como garantia dos cidadãos no sentido de que "nenhum tributo será exigido ou aumentado sem que a lei o estabeleça. " (art. 153, \& 29 da Const. Fed.) .

Apesar dessas duas referências expressas à legalidade da tributação, convém observar que elas somente especificam, realçam, o que, a rigor, já está implícito no princípio genérico de legalidade, nos termos do $\$ 2 .^{\circ}$ do artigo 153 da Const. Fed., quando reza:

"§ $2 .^{\circ}$ - Ninguém será obrigado a fazer ou deixar de fazer alguma coisa senão em virtude de lei."

\subsection{Conceito da legalidade tributária.}

De quanto ficou dito, colige-se que o princípio fundamental do Direito Tributário é o da legalidade dos tributos, que assim pode ser formulado: não haverá tributo sem lei que o institua. Em vista da analogia deste princípio com aquele que rege o Direito Penal, costuma-se dizer, parafraseando o aforismo de Feuerbach: "nullum tributum sine lege".

Historicamente, este princípio significa que a arrecadação de tributos pelo poder público deve ser autorizada previamente pelos representantes do povo. Além disso, implica na obrigação de a atividade impositiva da administração pública dever desenvolver-se através de normas jurídicas.

A limitação dos poderes do Estado teve, como já vimos no ítem anterior, sua primeira expressão nesse condicionamento do poder tributário do Estado. A partir daí, o princípio da legalidade se entendeu às demais atividades do Estado. Desta forma, o princípio da legalidade dos tributos não só 
constitui a "partida de nascimento" do Direito Tributário, como a própria base do Direito Constitucional, pois, como observa JARACH:

"não devemos olvidar que foi por razões tributárias que nasceu o Estado moderno de Direito" 15

Partindo da garantia individual específica contra uma tributação arbitrária, vários outros princípios de proteção do indivíduo contra o "imperium" do Estado foram paulatinamente conquistados através dos séculos, resultando na criação do moderno Estado de Direito. Assim, o Estado de Direito, ao lado do princípio da legalidade tributária, prevê os princípios genéricos da legalidade da administração, da segurança jurídica, da tutela jurisdicional e outros mais.

Esses novos princípios mantêm uma relação estreita com a matéria tributária constituindo, freqüentemente, novas modalidades ou aperfeiçoamentos do tradicional princípio da legalidade tributária. Assim, tendo em vista o Direito Positivo Brasileiro, podemos afirmar que a legalidade da tributação se apresenta sob as seguintes feições:

a) como legalidade da administração pública;

b) como reserva da lei;

c) como estrita legalidade tributária;

d) como conformidade da tributação com o fato gerador.

\section{As feições do princípio da legalidade tributária.}

41 Legalidade da administração.

$\mathrm{Na}$ opinião da maioria dos autores alemães, o princípio da legalidade da administração ("Gesetzmaessigkeit der

15. Dino Jarach, op. cit., pág. 24. 
Verwaltung"), consagrado pelo Estado de Direito, é o princípio básico, do qual decorrem todos os demais aspectos específicos ou feições da legalidade tributária. Freqüentemente, o princípio da legalidade da administração tem sido considerado como a encarnação do Estado de Direito. Assim, por exemplo, Walter Jeluinek o chamou de "princípio básico do Estado de Direito" 16

O princípio da legalidade da administração nasceu consuetudinariamente do direito dos representantes do povo autorizarem a tributação, tornando-se geral para o Direito Administrativo no século XIX.

Quanto ao conteúdo do princípio da legalidade da administração, são muitas as divergências e dúvidas ${ }^{17}$. Por um lado, para autores como MAunz, ele significa que todos os atos do Estado, fora a legislação, devem ter uma base legal, isto é, deve existir a possibilidade de "reconduzir" todas as intervenções do Estado na esfera jurídica do indivíduo à própria Constituição ou a uma lei em sentido formal ${ }^{18}$ Como representante da mesma corrente, WALTER JELlinex limita a validade desse princípio aos atos administrativos onerosos ${ }^{19}$

Do outro lado, autores como Peters defendem outra concepção da legalidade da administração, no sentido de que "as autoridades administrativas estão vinculadas ao direito e, portanto, também ao direito posto por elas próprias" ${ }^{20}$ Para estes autores, a administração está vinculada não só à lei formal mas sim ao direito, incluindo as próprias normas administrativas. A vinculação à lei no sentido formal constituiria decorrência de outro princípio mais específico, que é o da reserva da lei ("Vorbehalt des Gesetzes").

\footnotetext{
16. Walter Jellinek, Verwaltungsrecht, 2. Aufl., Berlin, 1928, pág. 84.

17. cf. KRUSE, Gesetzmaessige Verwaltung..., op. cit., págs. 96 e segs.

18. cf. MaUnz/DUERIG, op. cit., comentário 124.

19. WALter JeLIiNeK, op. cit., pág. 85.

20. Peters, Lehrbuch der Verwaltung, apud KRUSE, Gesetzmaessige... op. cit., pág. 97.
} 
Em vista do Direito Positivo Brasileiro, inclinamo-nos à opinião da segunda corrente. Pois, quando o Código Tributário Nacional, no seu artigo $3 .^{\circ}$, estabelece que o tributo é cobrado "mediante atividade administrativa plenamente vinculada", certamente não vincula esta atividade administrativa somente à lei formal, mas sim a toda a legislação tributária, tal como definida pelo art. 96 do mesmo Código. Na definição do art. 96, a expressão "legislação tributária" não só compreende as leis ordinárias, como ainda os tratados e as convenções internacionais, os decretos regulamentadores expedidos pelo Executivo, bem como as normas complementares, que abrangem os atos normativos, decisões e práticas das autoridades administrativas.

A mesma idéia da vinculação da administração a toda a legislação tributária está contida no § único do art. 142 do Código Tributário Nacional, quando determina:

"§ único - A atividade administrativa de lançamento é vinculada e obrigatória, sob pena de responsabilidade funcional."

O referido dispositivo, além da vinculação, indica, ainda, outra característica da atividade, a saber, a da sua obrigatorieđade. No Direito Tributário, o princípio da legalidade da administração não significa somente que os tributos devem ser cobrados em observância da legislação tributária, mas também que a administração é obrigada a cobrar o tributo nascido de acordo com a lei. Isto decorre do fato de que, modernamente, a lei não é somente barreira contra intervenções do Estado na esfera jurídica dos indivíduos, mas também a força motriz da atividade administrativa. A obrigação de apurar e cobrar o tributo, nascido na conformidade da lei, resulta do princípio da legalidade da administração.

4.2 Reserva da lei.

Dentro da concepção acima exposta, o princípio da reserva da lei constitui uma especificação do princípio da legali- 
çade da administração, vinculando-a não ao direito, de uma forma genérica, mas à lei formal. Por "lei formal" ou "lei no sentido formal" entendemos uma lei elaborada com a participação precípua da representação popular.

O princípio da reserva da lei é, portanto, um corolário da administração vinculada, condicionando as intervenções onerosas na esfera jurídica do indivíduo à existência de uma lei formal, isto é, emanada do poder legislativo. E o princípio enunciado pelo $\$ 2 .^{\circ}$ do art. 153 da Constituição Federal, nos seguintes termos:

"§ 2. ${ }^{\circ}$ - Ninguém será obrigado a fazer ou deixar de fazer alguma coisa senão em virtude de lei."

O princípio da reserva da lei, incluído no rol dos direitos e das garantias individuais, aplica-se, pois, a todos os atos administrativos onerosos, inclusive os de natureza tributária.

43 Estrita legalidade tributária.

O princípio da estrita legalidade da tributação decorre, implicitamente, do próprio princípio da reserva da lei. Tal é, porém, sua relevância para o Direito Tributário, que, como já vimos, a Constituição Federal o inclui expressamente em dois dispositivos distintos:

a) No art. 19, inciso I, dentro do capítulo que disciplina o Sistema Tributário Nacional:

"Art. 19 - É vedado à União, aos Estados, ao Distrito Federal e aos Municípios:

I - instituir ou aumentar tributo sem que a lei o estabeleça, ressalvados os casos previstos nesta Constituição .

Aqui, o princípio da estrita legalidade tributária se apresenta como proibição constitucional dirigida à administração 
federal, estadual e municipal de instituir ou aumentar tributos sem que haja uma lei que o autorize. O Código Tributário Nacional repete esse princípio restritivo da competência tributária no seu art. $9 .^{\circ}$, inciso $\mathrm{I}$.

b) No capítulo dos direitos e garantias individuais, o art. 153 , além de incluir no seu $\$ 20^{\circ}$ o já referido princípio genérico da reserva da lei, estabelece no seu \$29:

"\$29 - Nenhum tributo será exigido ou aumentado sem que a lei o estabeleça, nem cobrado em cada exercício, sem que a lei que o houver instituido ou aumentado esteja em vigor antes do início do exercício financeiro, ressalvados a tarifa alfandegária e a de transporte, o imposto sobre produtos industrializados e o imposto lançado por motivo de guerra e demais casos previstos nesta Constituição."

Como se về, o referido parágrafo não se limita a estabelecer o princípio da estrita legalidade dos tributos, como ainda determina o princípio da anualidade, porém sujeito a uma série de exceções. Nota-se, ainda, que a atual Constituição não mais vincula a legalidade da tributação à prévia autorização orçamentária.

Por sua vez, o Código Tributário Nacional dispõe no seu art. 97:

“Art. 97 - Somente a lei pode estabelecer: tinção;

I - a instituição de tributos, ou a sua ex-

II - a majoração de tributos ou sua redução, ressalvado o disposto nos artigos $21,26,39,57$ ";

Podemos concluir, pois, que a legalidade de um tributo somente se configura quando sua imposição for determinada pela autoridade competente e nos termos da Constituição. 
44 Conformidade da tributação com o fato gerador.

Em matéria tributária, e como corolário dos três princípios acima descritos, encontramos finalmente o princípio específico da conformidade da tributação com o fato gerador. Segundo este princípio, os tributos somente podem ser arrecadados depois de ocorrido o fato gerador ao qual a lei vincula a obrigação tributária. O nascimento da obrigação tributária está subordinado ao princípio da legalidade, na forma específica da conformidade com o fato gerador.

Assim, por força do princípio da legalidade tributária, exige-se que a lei formal determine todos os elementos constitutivos da obrigação tributária, ou seja, todos os aspectos do fato gerador. Uma lei que autoriza a cobrança de tributos não pode deixar ao critério da administração a diferenciação objetiva, ela própria tem que realizar esta diferenciação. E neste sentido que AmílCAR FALCÃO afirma:

"Definir, caracterizar, conceituar por lei o fato gerador do tributo é, entretanto, um dos aspectos mais relevantes do chamado princípio da legalidade dos tributos, ou da reserva da lei em matéria tributária" ${ }^{21}$.

Segundo a definição clássica de Hensel, por fato gerador do tributo ("Steuertatbestand") designamos "a totalidade dos pressupostos abstratos contidos nas normas materiais de Direito Tributário, cuja ocorrência deve resultar em determinados efeitos jurídicos" ${ }^{22}$

A teoria do fato gerador, que apresenta pronunciado paralelismo com o conceito da tipicidade que rege o Direito Pe-

21. Amilcar de AraúJo FalcÃo, Fato Getador da obrigação tributária, 2.a ed., São Paulo, 1971, pág. 37.

22. Albert Hensel, Steuerrecht, 3. Aufl. Berlin, 1933, pág. 57: "Als Steuertatbestand bezeichnen wir die Gesamtheit der in den materiellen Steurrechtsnormen enthaltenen abstrakten Voraussetzungen, bei deren konkretem Vorliegen (Tatbestandsverwirklichung) bestimmte Rechtsfolgen elntreten sollen". 
nal, foi acolhida, pela primeira vez, pelo Código Tributário da Alemanha ("Reichsabgab-enordnung"), em 1919, sendo hoje amplamente adotada pela doutrina e incluída nos diplomas legais.

Seguindo o conceito estabelecido pelo Código Tributário da Alemanha, o Código Tributário Nacional, no seu art. 114, dá a seguinte definição do fato gerador:

"Art. 114 - Fato gerador da obrigação principal é a situação definida em lei como necessária e suficiente à sua ocorrência" (o grifo é nosso) . estabelece:

Por sua vez, o art. 115 do Código Tributário Nacional

"Art. 115 - Fato gerador da obrigação acessória é qualquer situação que, na forma da legislação aplicável, impõe a prática ou a abstenção de ato que não configure obrigação principal" (O grifo é nosso)

Do confronto dos dois dispositivos decorre que o nascimento da obrigação tributária principal depende de lei no sentido formal, eis que ela tem por objeto o pagamento de tributo ou penalidade pecuniária, enquanto que as obrigações acessórias, que tem por objeto formalidades no interesse da arrecadação ou da fiscalização, encontram sua fonte em qualquer espécie de legislação tributária, tal como definida pelo já mencionado art. 96 do CTN. Com outras palavras, a obrigação tributária principal se rege pelos princípios específicos da reserva da lei formal e da estrita legalidade tributária, enquanto que a obrigação acessória somente está sujeita ao princípio genérico da legalidade da administração.

Assim, o já mencionado art. 97 do crN, que, nos seus ítens I e II, reserva a instituição e majoração dos tributos à lei formal, somente se refere à obrigação principal, quando dispõe: 
“Art. 97 - Somente a lei pode estabelecer:

I - II - . .

III - a definição do fato gerador da obrigação tributária principal. ., e do seu sujeito passivo;

IV - a fixação da alíquota do tributo e da sua base de cálculo,

Diferentemente, as obrigações tributárias acessórias podem ser estabelecidas através de qualquer norma jurídica.

O princípio da conformidade da tributação com o fato gerador tem estrutura obrigacional e pressupõe leis no sentido formal. Na obrigação tributária principal, de Direito Público, o requisito da vontade, imprescindível à obrigação de Direito Privado, é substituido pela vontade da lei, manifesta na descrição do fato gerador ${ }^{23}$ A lei formal descritiva do fato gerador deve, portanto, relacionar todos os aspectos do fato gerador, necessários à configuração da obrigação tributária, a saber ${ }^{24}$ :

a) aspecto objetivo ou material, que consiste na definição da situação de fato, que servirá de base à imposição;

b) aspecto subjetivo, que determina os sujeitos ativo e passivo da obrigação tributária;

c) aspecto espacial, que indica o lugar onde se realiza o fato gerador objetivo, determinando a lei aplicável;

d) aspecto temporal, que fixa o momento da ocorrência do fato gerador;

e) aspecto quantificativo, que fornece a base de cálculo e a alíquota.

23. cf. RUY Barbosa Nogueira, Direito Financeiro, 3. ${ }^{a}$ ed., São Paulo, 1971, pág. 121.

24. cf. RUY Barbosa Noguetra, op. cit., págs. 114 e segs. 
Sem essa previsão ou definição em lei do fato gerador, em todos os seus aspectos, não nascerá nenhuma obrigação tributária principal. Os fatos da vida real, de natureza econômica, somente se tornam relevantes para o. Direito Tributário, dando origem ao nascimento de uma obrigação, quando corresponderem aos fatos geradores descritos em lei. Portanto, sem definição em lei não há fato gerador, sem ocorrência do fato gerador não há obrigação tributária.

\section{O conceito de "lei" para efeitos do princípio da estrita legalidade tributária - Legalidade material e formal.}

Conforme já vimos, diferentemente do princípio genérico da legalidade da administração, o princípio da estrita legalidade tributária exige leis no sentido formal, isto é, leis emanadas do Poder Legislativo, na forma prevista pela Constituição. E da essência do princípio da legalidade tributária, que as leis que instituam obrigações tributárias principais sejam elaboradas pelo órgão de representação popular. A sua origem histórica está vinculada a esta idéia.

No Estado de Direito, que se caracteriza pela separação dos poderes, somente se pode falar em legalidade da tributação quando as leis tributárias são elaboradas por um órgão distinto daquele que tem a função de aplicá-las. Nas palavras de Aliomar Baleeiro:

"O tributo é ato de soberania do Estado na medida em que sua cobrança é autorizada pelo povo, através da representação" 25

Mesmo os autores que, como Orlando e Lolini, negam à lei tributária o caráter de verdadeira norma jurídica, qualificando-a como simples ato administrativo, reconhecem, no 
entanto, a competência exclusiva do Congresso para a sua elaboração ${ }^{28}$

VICTOR UCKMar, examinando as modernas Constituições, constata que esta regra está prevista na quase totalidade delas:

"La criazione delle imposte, con la individualizzazione dei soggetti, dell'oggetto e dei criteri per determinare il quantum, compete in via esclusiva al potere legislativo" 27

Historicamente, os regimes democráticos se caracterizam pelo direito de os contribuintes consentirem, pelo voto de seus representantes eleitos, na criação ou aumento de tributos: "no taxation without representation" 28

O exame do atual Direito Positivo Brasileiro mostra, no entanto, que a competência privativa do Congresso de instituir e aumentar tributos sofreu ultimamente uma série de restrições, que põem em perigo a própria validade do princípio da legalidade tributária. De fato, a competência do Poder Legislativo sofreu as seguintes restrições, em benefício do Poder Executivo:

a) Ressalvas ao princípio da legalidade tributária. O $\$ 29$ do art. 153 ressalva, na sua parte final, a tarifa alfandegária e a de transporte, o imposto sobre produtos industrializados e o imposto lançado por motivo de guerra e demais casos previstos na Constituição. Essas exceções prevêm, relativamente aos impostos indiretos mencionados, a possibilidade de suas alíquotas ou bases de cálculo poderem ser alteradas pelo Poder Executivo, nas condições e limites estabelecidos em lei, afim de adaptá-las às finalidades extrafiscais enunciadas no art. $21, \S 4 .^{\circ}$ da Constituição Federal. No entanto, é

26. cf. Dino Jarach, op. cit., pág. 103.

27. Victor UCKMAR, op. cit., pág. 30.

28. cf. Altomar Balestro, Direito Tributário Brasileiro, 3.a ed., Rio, 1971, pág. 78. 
importante ressalvar que a competência outorgada ao Poder Executivo é subordinada aos limites mínimo e máximo da lei.

b) Eliminação da prévia autorização orçamentária. Nos termos do $\$ 34$ do art. 141 da Constituição de 1946, a obrigação tributária não dependia somente da lei (princípio da legalidade), senão também da prévia autorização orçamentária. A Emenda n. ${ }^{\circ}$ 18, de 1-12-1965, no seu art. 25, revogou expressamente a exigência da prévia autorização orçamentária. Posteriormente, o \$ 29 do art. 150 da Const. Fed. de 1967 a restaurou, com a mesma redação do art. 141, \$ 34 da Const. de 1946.

Com a vigência do $\$ 29$ do art. 153 da Const. Fed., na redação da Emenda Constitucional n. ${ }^{\circ}$ 1/1969, a prévia autorização orçamentária deixou novamente de ser exigida. Atualmente é suficiente que a lei do tributo seja anterior ao exercício no qual é cobrado, não mais se exigindo sua inclusão na lei orçamentária, o que, nas palavras de Aliomar Baleeiro, constitui "a negação de um princípio básico da democracia" 29

c) Os decretos-leis sobre matéria tributária. Abrindo exceção ao princípio democrático da separação dos poderes, o art. 55 da Const. Fed. prevê que o Presidente da República, "em casos de urgência ou de interesse público relevante", poderá expedir decretos-leis sobre:

$$
\text { "Art. } 55 \text { - }
$$$$
\text { I - }
$$

II - finanças públicas, inclusive normas tri-
butárias;.

Na opinião dos autores pátrios, o decreto-lei não é meio idôneo para instituir ou aumentar tributos, o que, nos termos do art. 153, \$ 29 cabe à lei, e só à lei ordinária, salvo

29. Aliomar Baleeiro, Direito Tributário Brasileiro, op. cit., pág. 83. 
casos específicos de leis complementares ${ }^{30}$ Conforme esclarece Manoel Gonçalves Ferreira Filho, o art. 55, II, “daria ao Presidente da República o poder de alterar a regulamentação de um tributo por meio de um decreto-lei mas não o autoriza a criá-lo "ex-nihilo", ou aumentar-lhe a alíquota" 31 Além do mais, a legitimidade do decreto-lei dependeria da sua própria conceituação de legislação extraordinária, de modo que o decreto-lei só se justificaria em casos de urgência ou de interesse público relevante ${ }^{32}$

Na realidade impositiva, no entanto, não é isto que se observa. Verificamos, pelo contrário, que o Poder Executivo, cada vez mais frequientemente, utiliza os decretos-leis para legislar sobre os elementos constitutivos da obrigação tributária, sem ao menos atentar aos requisitos da urgência ou do interesse público relevante.

Assim, sempre que a administração fiscal vê frustrada uma pretensão por falta de base legal, ela própria, através da publicação de um decreto-lei, cria as condições necessárias para fazer prevalecer sua pretensão, alterando ou mesmo revogando leis ordinárias, pondo de lado jurisprudência pacífica.

Como exemplo, entre muitos, podemos citar o caso do recente Decreto-lei n. ${ }^{\circ} 1$ 198, de 27-12-1971, através do qual foi conferida ao Ministro da Fazenda a competência de estabelecer condições e limites às deduções permitidas na cédula $\mathrm{D}$ da declaração de rendimentos da pessoa física. Desta forma, foi criada a condição "legal" para uma alteração da base de cálculo do imposto de renda, anteriormente repelida pela doutrina e pela jurisprudência como ilegal.

Em vista dessa prática, o princípio da legalidade, de certa

30. cf. Aliomar Baleeiro, Direito Tributário Brasileiro, op. cit. págs. 65 e 359.

31. Manoel Gonçalves Ferretra Filho, Curso de Direito Constitucional, 3. ${ }^{\mathrm{a}}$ ed. São Paulo, 1971, pág. 144.

32. cf. Nelson de Sousa Sampaio, Os decretos-leis e sua seara, in Rev. de Direito Público, n.o 3/1968, pág. 27. 
forma, perdeu seu conteúdo material para transformar-se em princípio meramente formal. A nada, ou pelo menos quase nada, se reduz a garantia individual da legalidade da tributação, quando ao Poder Executivo, encarregado da cobrança dos tributos, se permite, ao mesmo tempo, legislar sobre a matéria. $\mathrm{O}$ fato de os decretos-leis deverem ser aprovados pelo Congresso Nacional, pouco altera dessa situação anômala.

Devido às restrições e inovações acima referidas, é forçoso concluir que, no Direito Brasileiro vigente, o princípio da legalidade tributária está perdendo cada vez mais seu conteúdo material, sendo mantido apenas no seu aspecto formal.

\section{O princípio da legalidade tributária e a aplicação e interpretação das leis tributárias.}

Neste capítulo, examinaremos as conseqüências do princípio da legalidade tributária em relação à aplicação e interpretação das leis tributárias. Como esta matéria é muito complexa e, a rigor, já ultrapassa os limites do presente trabalho, limitar-nos-emos a apontar o problema central de cada item, sem maiores demonstrações ou ilustrações.

6.1 Aplicação das leis tributárias.

A aplicação da lei tributária consiste na apuração da situação de fato e sua subsunção ao fato gerador previsto em lei. Quanto à forma, a aplicação das leis tributárias se realiza através de um silogismo: o fato gerador legal constitui a premissa maior, a situação de fato a premissa menor e a subsunção, isto é, a determinação do efeito jurídico concreto, constitui a conclusão. Assim sendo, a aplicação da lei tributária se processa em três fases ${ }^{33}$ :

a) apuração da situação de fato, isto é, dos fatos concretos; já nesta parte pode haver necessidade de in-

33. cf. KURT BARSise, Reichsabgabenordnung, 7. Aufl, Stuttgart, 1965, págs. $17 / 18$. 
terpretação para melhor compreensão dos fatos efetivamente ocorridos, principalmente quando as manifestações de vontade das partes dão margem a dúvidas;

b) verificação da lei aplicável, sendo necessária, freqüentemente, a interpretação a fim de determinar o conteúdo exato e alcance da lei;

c) subsunção, isto é, a sujeição da situação de fato apurada e interpretada à lei, igualmente apurada e interpretada.

Para a aplicação certa da lei tributária é necessária, portanto, a correta interpretação da lei e o perfeito conhecimento da situação de fato. Em virtude do princípio da legalidade tributária, na interpretação, tanto da lei como da matéria fática, devem ser observadas regras específicas, das quais trataremos no item seguinte.

\subsection{Interpretação das leis tributárias.}

A interpretação consiste em esclarecer o sentido de uma norma jurídica. $\mathrm{O}$ esclarecimento do sentido muitas vezes se faz mister quando o texto de uma norma jurídica exprimir seu conteúdo de forma imperfeita, dando margem a dúvidas quanto ao seu verdadeiro significado e alcance.

Conforme a opinião dominante na doutrina, a finalidade da interpretação consiste em atingir-se com exatidão a intenção da lei, a "mens legis", isto é, a vontade objetivada do legislador (teoria objetiva da interpretação) Para tanto, na aplicação das leis tributárias, são admissíveis todos os métodos e processos de interpretação, consagrados pela hermenêutica, tais como os métodos gramatical, sistemático, teleológico e histórico.

Diferentemente dos outros ramos do direito, o Direito Tributário, na legislação de vários países, codificou certas regras de interpretação das leis tributárias. Assim, por exemplo, 
o Código Tributário da Alemanha, no seu $\$ 4 .^{\circ}$, incluiu o seguinte dispositivo sobre a interpretação:

"Bei Auslegung der Steuergesetze sind ihr Zweck, ihre wirtschaftliche Bedeutung und die Entwicklung der Verhaeltnisse zu beruecksichtigen"

ou em vernáculo:

"Na interpretação das leis tributárias devem ser levadas em consideração sua finalidade, seu sentido econômico e o desenvolvimento das relações."

Com base nesta regra, da qual resultou o $\$ 1 .^{\circ}$, incisos II e III da Lei de Adaptação Tributária ("Steueranpassungsgesetz"), se desenvolveu, na Alemanha, uma teoria de interpretação especificamente tributária. Tema central dessa teoria é a chamada "consideração econômica", da qual trataremos no item 6.4 abaixo.

No Brasil, o Código Tributário Nacional traz uma série de regras especiais de interpretação das leis tributárias, tais como as dos artigos 99 e 118, e ainda um capítulo inteiro, sob o título "Interpretação e Integração da Legislação Tributária" (arts. 107 a 112) A enumeração das regras de interpretação contidas no CTN, no entanto, não é taxativa, sendo permitidas todas as regras consagradas pelos outros ramos do direito.

A interpretação, no entanto, sempre deverá ser realizada em observância dos princípios da estrita legalidade tributária e da conformidade com o fato gerador. Desta forma, nenhum método de interpretação pode resultar em criação ou modificação de tributo. Pois, como afirma o Prof. Ruy Barbosa NoGUEIRA:

"Se a lei não o previu, ele não pode surgir ou 
tornar-se maior ou menor, por outra via. O tributo só existe se criado por lei e na medida por ela cria$\mathrm{da}{ }^{34}$.

6.3 Integração das leis tributárias.

Como vimos, através da interpretação é apurado e esclarecido o verdadeiro sentido da lei. Pela integração, o conteúdo da lei é completado ou modificado. Para caracterizar esta diferença entre interpretação e integração, podemos dizer, portanto, que a interpretação consiste num processo cognitivo, enquanto que a integração representa um processo volitivo ${ }^{35}$

A integração pressupõe sempre a existência de uma lacuna da lei, isto é, a falta de um dispositivo legal adequado. Essa lacuna pode ser "intra legem" ou "praeter legem"

Falamos em lacunas "intra legem", quando o legislador não definiu integralmente sua intenção, utilizando-se, pelo contrário, de conceitos jurídicos indeterminados ${ }^{36}$ Portanto, a integração das lacunas "intra legem" consiste na determinação dos conceitos jurídicos indeterminados contidos na lei.

As demais lacunas são denominadas "praeter legem" Elas devem ser preenchidas da forma pela qual o legislador teria regulado a questão se a tivesse conhecido. Para tanto, devem ser considerados o sentido da lei e a vontade do legislador nela objetivada.

O Código Tributário Nacional, no seu art. 108, estabelece uma série de métodos a serem utilizados na integração da legislação tributária:

"Art. 108 - Na ausência de disposição expres-

34. RUy Barbosa Nogueira, Da Interpretação e da Aplicação das Leis Tributárias, 2.a ed., São Paulo, 1965, pág. 24.

35. cf. KRUSE, Steuerrecht, op. cit., pág. 70

36. cf. Gerd Willi RothmanN, O Standard Juridico, in Revista dos Tribunals, vol. 371, págs. 9 e segs. 
sa, a autoridade competente para aplicar a legislação tributária utilizará sucessivamente, na ordem indicada:

$$
\text { I - a analogia; }
$$

II - os princípios gerais de direito tributário;

III - os princípios gerais de Direito Público;

IV - a eqüidade.

$\S 1 .^{\circ}-\mathrm{O}$ emprego da analogia não poderá resultar na exigência de tributo não previsto em lei.

$\S 2 .^{\circ}$ - O emprego da eqüidade não poderá resultar na dispensa do pagamento de tributo devido."

$\mathrm{O} \S 1 .^{\circ}$ do referido artigo é categórico em afirmar que a analogia não pode criar tributo não previsto em lei, ou, com outras palavras, não pode estabelecer novos fatos geradores. Esta proibição, aliás, já decorre do princípio da estrita legalidade tributária e da conformidade da tributação com o fato gerador.

Conforme já vimos por ocasião do exame dos artigos 113 e 114 do Código Tributário Nacional, a obrigação tributária principal, isto é, aquela que consiste no pagamento de tributo ou penalidade pecuniária, nasce com a ocorrência do fato gerador ao qual a lei vincula o débito tributário. Disso segue, "contrario sensu", que não nasce nenhum débito tributário se o fato gerador legal não fôr realizado.

Em vista disso, qual é o âmbito do emprêgo da analogia no Direito Tributário? Concordamos com o Prof. Ruy Barbosa NogueIra, que restringe a aplicação da analogia ao campo do Direito Tributário formal, ou seja, ao campo das obrigações acessórias ${ }^{37}$

37. cf. Ruy Barbosa Nogueira, Direito Financeiro, op. cit., pág. 77. 
Pela mesma ordem de idéias, o emprêgo da equidade não pode resultar na dispensa do pagamento de tributo devido. A obrigação tributária principal é estritamente "ex lege", de Direito Público, não tendo as partes a disponibilidade da relação jurídico-tributária.

Concluímos, pois, que os métodos de integração, em virtude do princípio da estrita legalidade tributária, não podem constituir os elementos da obrigação tributária principal, ficando seu emprego restringido ao campo das obrigações acessórias, meramente formais.

\subsection{Consideração econômica.}

6.41 Natureza econômica das leis tributárias.

Os pressupostos de fato da tributação são sempre de natureza econômica, visto que através da tributação o Estado visa arrecadar uma parcela da riqueza privada, a fim de obter os meios materiais necessários à realização dos seus fins. Eis porque as leis tributárias, por natureza, se vinculam a fatos e relações econômicas, que revelam a capacidade econômica do contribuinte.

Reconhecendo o conteúdo econômico das leis tributárias, a Constituição de 1946 estabelecia, no seu art. 202, a seguinte norma programática:

"Art. 202 - Os tributos terão caráter pessoal sempre que isso fôr possível, e serão graduados conforme a capacidade econômica do contribuinte"

Apesar de a Constituição vigente não contemplar mais essa regra de forma expressa, o princípio da capacidade econômica do contribuinte continua regendo implicitamente a legislação tributária, pois, como afirma Wurlod:

"O Direito Tributário deve realizar dentro das 
formas do direito os fins econômicos propostos pelas outras ciências financeiras" 38

A capacidade econômica ou contributiva, no entanto, frequientemente só pode ser apurada por critérios econômicos e não pela forma jurídica de que se revestem determinados fatos, situações ou relações. Assim, uma consideração econômica realmente se impõe ao exegeta das leis tributárias. Por isso, ENNo Becker sempre afirmou que nem ele, como autor do Código Tributário da Alemanha (AO), nem a Côrte Tributária da Alemanha ("Reichsfinanzhof", hoje "Bundesfinanzhof") "inventaram" a chamada consideração econômica, que se desenvolveu, principalmente na Alemanha, a partir da promulgação da AO.

6.4.2 Aspectos da consideração econômica.

Na Alemanha, a base legal da consideração econômica foi introduzida pelo $\$ 4 .^{\circ}$ da Ao de 1919 , que dispunha que, na interpretação das leis tributárias, devia ser levado em consideração o seu sentido econômico. Este dispositivo posteriormente foi acolhido pela Lei de Adaptação Tributária ("Steueranpassungsgesetz"), que, no seu $\$ 1 .^{\circ}$, estabelece:

"\$ $10^{\circ}-$

I - revogado;

II - Para tanto, deverão ser levados em consideração a concepção popular, a finalidade e o sentido econômico das leis tributárias e o desenvolvimento das relações.

III - O mesmo se aplica à apreciação dos elementos de fato" ${ }^{39}$

38. Marcel WuRLoD, Forme Juridique et Réalité Economique dans l'application des lois fiscales, Lausanne, 1947, pág. 21.

39. Steueranpassungsgesetz

$\S 1.0^{\circ}-\ldots$

I - Fortgefallen

II - Dabel sind die Volksanschauung, der Zweck und die wirtschaftliche Bedeutung der Steuergesetze und die Entwicklung der Verhaeltnisse zu beruecksichtigen.

III - Entsprechendes gilt fuer die Beurteilung von Tatbestaenden. 
A inovação da Lei de Adaptação (StAnpG) está no item III, em que reforça a aplicação da consideração econômica, que também deverá ser empregada na apreciação dos elementos de fato. Assim, a StAnpG mostra claramente que a consideração econômica se apresenta sob dois aspectos diversos: na interpretação das leis tributárias e na apreciação dos elementos ou situação de fato.

a) Na interpretação das leis tributárias (StAnpG $\$ 1 .^{\circ}$, II) , a consideração econômica nada mais representa que um método sistemático e teleológico, perfeitamente adequado ao princípio da legalidade. Considerando o conteúdo econômico da lei tributária, o $\$ 1 .^{\circ}$, StAnpG exige uma exata interpretação do texto legal, que corresponda ao seu sentido econômico. Portanto, neste primeiro aspecto, como princípio de interpretação, a consideração econômica metodologicamente não tem importância diversa das regras gerais de interpretação, consagradas pelos demais ramos do direito ${ }^{40}$

b) Na apreciação dos elementos de fato (StAnpG $\$ 1 .^{\circ}$, III) , a consideração econômica visa determinar a "verdadeira" situação de fato, no sentido de apurar-lhe o verdadeiro sentido econômico. Nisto, deve ser levado em consideração o verdadeiro conteúdo econômico dos elementos de fato e não a sua manifestação externa. Com outras palavras, a situação de fato deve ser apreciada de acordo com o resultado econômico realmente visado pelas partes.

Visando conseguir o não pagamento ou a redução de determinado tributo, os contribuintes freqüentemente manipulam as formas jurídicas. Por isso, ao intérprete impõe-se verificar, em cada caso concreto, se a "intentio juris" coincide com a "intentio facti", ou seja, se a forma jurídica da qual se reveste a situação de fato coincide com seu verdadeiro conteúdo econômico.

40. cf. ARNdT RAUPACH, Der Durchgriff im Steuerrecht, Muenchen, 1968, pág. 196. 
Como a consideração econômica, neste seu segundo aspecto, visa apurar a verdadeira situação de fato, ela autoriza o exegeta a por de lado a forma jurídica para alcançar o substrato econômico subjacente. Essa possibilidade de "superar" a forma jurídica para alcançar o negócio subjacente não é defendida somente no Direito Tributário, através da consideração econômica, mas no próprio Direito Civil, pela chamada "Durchgriffslehre"

Esta teoria, que poderíamos designar como "teoria da prevalência do substrato sobre a forma", trata das hipóteses em que é necessário por de lado a separação entre a pessoa jurídica e seu substrato pessoal, ou seja, as pessoas físicas que a compõem. E a problemática que na Itália é estudada como "il superamento della personalità giuridica delle società di capitali", sendo que no Direito norte-americano esta teoria é aplicada "to lift the veil"

Também neste segundo aspecto, a consideração econômica não se contropõe ao princípio da legalidade. Com muita propriedade, Amilcar FaLCÃo observa:

"Verdeiramente, o que existe aí é a recíproca do dever de legalidade a que está sujeita a própria administração: se o esquema legal da tributação é vinculante para o Estado, não há por que deixar de sê-lo para o contribuinte" ${ }^{41}$

Por outro lado, cabe destacar que a consideração econômica também se justifica pelo princípio constitucional da isonomia. O princípio da igualdade jurídico-tributária exige que, apesar da liberdade de estruturação de que goza o contribuinte, hipóteses economicamente iguais devem ser tratadas de forma igual. Na tributação não deve ser considerado somente o interesse do contribuinte, mas também da coletividade, isto

41. Amilcar de ARaújo FalCÃo, Introdução ao Direito Tributário, Parte Geral, ed. Financeiras, 1959, pág. 135. 
é, dos demais contribuintes. A justiça social, na forma de uma distribuição uniforme dos encargos fiscais, somente pode ser alcançada em observância ao princípio da isonomia, que, por isso, muitas vêzes, deve prevalecer sobre uma legalidade puramente formal.

A consideração econômica, no entanto, não pode ser utilizada para impor uma situação de fato inexistente. Por isso, é inadmissível a chamada "teoria dos tipos" ("Typisierende Betrachtungsweise"), igualmente uma elaboração germânica. Enquanto que a consideração econômica visa apurar a verdadeira situação de fato, o teoria dos tipos põe de lado a verdadeira situação de fato, passando a adotar uma situação "típica", que na realidade não ocorreu.

Dentro da observância dos princípios da legalidade tributária e da isonomia, concluímos, pois, que a consideração econômica, é admissível nas hipóteses de tributação de negócios simulados, ilegais ou ofensivos aos bons costumes, nulos ou anuláveis e daqueles que representam um abuso das formas e conceitos do Direito Civil.

\subsection{Retroatividade das leis tributárias.}

Outro corolário do princípio da legalidade tributária se refere à questão da aplicação retroativa das leis tributárias (42) Nesta questão, não se trata mais das limitações da administração fiscal, mas das do próprio legislador.

A ordem jurídica visa proporcionar a segurança jurídica, que deve garantir a previsibilidade do resultado das ações humanas. Isto significa que as leis tributárias devem ser baixadas em tempo, para que os contribuintes possam levá-las em consideração, nas suas disposições econômicas. Leis onerosas retroativas representam, portanto, uma séria ameaça à própria segurança jurídica.

42. Cf. Dino JARACH, op. cit., pág. 112. 
A retroatividade das leis tributárias tornaria inócuo o princípio da legalidade, até certo ponto, pois êste princípio deve permitir ao cidadão a previsão das intervenções na esfera de sua liberdade. Por isso, o princípio da legalidade tributária não significa somente que a pretensão do Fisco deve ter base em lei, mas ainda em lei anterior aos fatos, cuja tributação se pretende.

Eis porque o Código Tributário Nacional é categórico em proibir a aplicação retroativa das leis tributárias (art. 105, CTN), a não ser que se trate de leis meramente interpretativas ou que beneficiem o próprio contribuinte (art. 106, I e II CTN)

\section{Conclusões.}

7. 1 O princípio da legalidade tributária é o fundamento de tôda a tributação, sem o qual não há como se falar em Direito Tributário.

7. 2 Tendo nascido com a função precípua de prover as necessidades coletivas, o Estado forçosamente há de estar munido do poder de exigir dos indivíduos uma participação nos encargos financeiros.

7. 3 E em virtude do princípio da legalidade que a relação jurídico-tributária se caracteriza como relação de direito e não de poder.

7. 4 Do princípio do Estado de Direito decorre que o Estado, no exercício da tributação, também deve ser "justo", no sentido de salvaguardar a justiça e os direitos de liberdade e propriedade dos contribuintes, sujeitos ao seu poder impositivo.

75 O princípio da legalidade ou reserva da lei, tal como hoje se apresenta no $\$ 2 .^{\circ}$ do art. 153 da Const. Fed., tem sua origem ligada à tributação.

76 Tôdas as constituições vigentes, com exceção da 
Constituição da União Soviética, contêm dispositivo expresso, exigindo a aprovação dos impostos pelos órgãos legislativos competentes.

77 A legalidade da tributação, também no Direito Brasileiro vigente, se apresenta sob as seguintes feições:

a) como legalidade da administração pública;

b) como reserva da lei;

c) como estrita legalidade tributária;

d) como conformidade da tributação com o fato gerador.

7. 8 No Direito Tributário o princípio da legalidade da administração não significa somente que os tributos devem ser cobrados em observância da legislação tributária, no sentido amplo, mas também que a administração é obrigada a cobrar o tributo, desde que nascido de acôrdo com a lei.

7. 9 O princípio da reserva da lei é um corolário da legalidade da administração, condicionando as intervenções onerosas na esfera jurídica do indivíduo à existência de uma lei formal, isto é, emanada do Poder Legislativo.

710 O nascimento da obrigação tributária está subordinado ao princípio da estrita legalidade tributária, na forma específica da conformidade com o fato gerador.

711 A obrigação tributária principal se rege pelos princípios específicos da reserva da lei formal e da estrita legalidade tributária, enquanto que a obrigação tributária acessória somente está sujeita ao princípio genérico da legalidade da administração.

712 Sem definição em lei não há fato gerador, sem ocorrência do fato gerador não há obrigação tributária. 
713 No Estado de Direito, que se caracteriza pela separação dos poderes, somente se pode falar em legalidade da tributação quando as leis tributárias são elaboradas por um órgão distinto daquele que tem a função de aplicá-las.

714 O decreto-lei não é meio idôneo para instituir ou aulmentar tributos, o que, nos têrmos do art. $153, \S$ 29 da Const. Fed., cabe à lei, e só à lei ordinária.

715 No direito brasileiro vigente, o princípio da legalidade tributária está perdendo cada vez mais seu conteúdo material, sendo mantido apenas no seu aspecto formal.

716 Para a aplicação certa da lei tributária é necessário a correta interpretação da lei e o perfeito conhecimento da situação de fato.

717 Devido ao princípio da estrita legalidade tributária, nenhum método de interpretação pode resultar em criação ou modificação de tributo.

7.18 Os métodos de integração das leis tributárias - como por exemplo a analogia - em virtude do princípio da estrita legalidade tributária, não podem constituir os elementos da obrigação tributária principal, ficando seu emprêgo restringido ao campo das obrigações acessórias, meramente formais.

$719 \mathrm{Na}$ interpretação das leis tributárias, a chamada "consideração econômica" nada mais representa que um método sistemático e teleológico, perfeitamente compatível com o princípio da legalidade tributária.

7.20 A consideração econômica, na apreciação dos elementos de fato, tem sua base no princípio da isonomia, não podendo, no entanto, ser utilizada para impor uma situação de fato inexistente, como pretende a chamada "teoria dos tipos". 
7.21 Dentro da observância dos princípios da legalidade tributária e da insonomia, a consideração econômica é admissível nas hipóteses de tributação de negócios simulados, ilegais ou ofensivos aos bons costumes, nulos ou anuláveis e dos que representam um abuso das formas e conceitos do Direito Civil.

7.22 O princípio da estrita legalidade da tributação não significa somente que a pretensão do Fisco deve ter base em lei, mas ainda, em lei anterior aos fatos, cuja tributação se pretende.

\section{Bibliografia.}

Albert Hensel, Steuerrecht, 3. Aufl. Berlin, 1938.

Aliomar Baleeiro, Limitaçóes Constitucionais ao Poder de Tributar, Rio, 1951.

Aliomar Baleeiro, Direito Tributário Brasileiro, 3. ${ }^{\text {a }}$ ed., Rio, 1971.

Amf́lcar DE ARaúJo Falcão, Fato Gerador da obrigação Tributária, 2. ${ }^{\mathrm{a}}$ ed., São Paulo, 1971.

Artílcar de ARaújo Falcão, Introdução ao Direito Tributário, Parte Geral, Ed. Financeiras, 1959.

Antonio J. Franco de Campos, Das Garantias Juridicas no Direito Tributario, in "Direito Tributário" 3.a Coletânea, São Paulo, 1971.

ARNDT RAUPACH, Der Durchgrff im Steuerrecht, Muenchen, 1968.

DiNo JaRACH, Curso Superior de Derecho Tributário, ed. nueva, Buenos Aires, 1969.

Gerd Willi RothmanN, o standard Juridico, in Rev. dos Tribunais, vol. 371.

H. W. KRUSE, Steuerrecht, I Allg. Teil, 2. Aufl., Muenchen 1969.

H. W. KRUSE, Gesetzmaessige Verwaltung, Tatbestandsmaessige Besteuerung. in "Vom Rechtsschutz im Steuerrecht", Duesseldorf, 1960.

J. M. de Arruda Alvim NetTo, Da Jurisaição, in Rev. de Direito Público, n. ${ }^{\circ}$ $13 / 70$.

JUERGeN SALZWEDEL, Rechtsstaat im Steuerrecht, in "Vom Rechtsschutz in. Steuerrecht”, Duesseldorf, 1960.

KURT BARSKE, Reichsabgabenordnung, 7. Aufl., Stuttgart, 1965.

Manoel Gonçalves Ferreira Filfo, Curso de Direito Constitucional, 3.a ed. São Paulo, 1971.

Marcel Wurlod, Forme Juridique et Réalité Économique dans L'application des los Fiscales, Lausanne, 1947. 
Maunz/Dugrig, Grundgesetz, Loseblatt-Kommentar.

Netson DE Sousa SAMpaIo, Os decretos-leis e sua seara, in Rev. de Direito Público n.0 3/1968.

PaUlino JaCques, Curso de Direito Constitucional, $3 .^{a}$ ed., São Paulo/Rio, 1962.

RUy Barbosa Nogueira, Direito Financeiro, 3.a ed., São Paulo, 1971.

RUY Barbosa Nogueira, Da Interpretaçäo e da Aplicação das Leis Tributárias, 2. ${ }^{a}$ ed., São Paulo, 1965.

Victor UCKmar, Principi Comuni di Diritto Costituzionale Tributario, Padova, 1959.

WALter JeLlineK, Verwaltungsrecht, 2. Aufl. Berlin, 1928. 